PRINT ISSN 1119-8362

Electronic ISSN 1119-8362
Full-text Available Online at

https://www.ajol.info/index.php/jasem

http://ww.bioline.org.br/ja
J. Appl. Sci. Environ. Manage.

Vol. 24 (9) 1551-1554 September 2020

\title{
Economic Analysis of Cassava Flour and Garri Production in Ibarapa Local Government Area, Oyo State, Nigeria
}

*11ADESOPE, AA; ${ }^{1}$ OLUMIDE-OJO, O; ${ }^{2}$ OYEWO, IO; ${ }^{2}$ UGEGE, BH; ${ }^{1}$ OYELADE, AA

${ }^{I}$ Forestry Research Institute of Nigeria, Ibadan, Nigeria $;{ }^{2}$ Federal College of Forestry, P.M.B 5087 Jericho hill Ibadan, Nigeria *Corresponding Author Email: adesope.aa@frin.gov.ng

\begin{abstract}
Cassava, an edible root crop and a reliable and relatively inexpensive source of carbohydrate, is widely grown and processed into different foods such as cassava flour and garri. The study analyzed the costs and returns in cassava flour and garri production and also determined the factors influencing its production in the study area. A two- stage sampling technique was used to generate primary data used for this study. The first stage involved the purposive selection of Ibarapa North Local Government Area (LGA), because it has more cassava producers and processors than other LGAs. The second stage involved the random selection of 15 villages out of the 23 in the LGA. From the selected villages, 170 respondents were randomly selected while only 150 copies of the structured questionnaire administered were retrieved. Results from the primary data shows that $28.3 \%$ of garri producersproducers had no formal education and $46.7 \%$ were between the ages of 30 and 39years. The regression analysis shows that the quantity of garri sold $(\beta=5.4099)$, transportation cost $(\beta=-0.2994)$, peeling cost $(\beta=-0.4249)$, and grating cost $(\beta=0.6878)$ were all significant to the total revenue of cassava flour sold. Price, inadequate capital, transportation, land tenure and markets were factors influencing garri and cassava flour production. Analysis of the costs and returns revealed that processing cassava into garri gave a higher gross margin even though processing of cassava was profitable, indicating that there is a significant difference between flour and garri production. Inputs, market, good and infrastructural facilities should be provided so as to increase production capacity and hence food security.
\end{abstract}

DOI: https://dx.doi.org/10.4314/jasem.v24i9.11

Copyright: Copyright (C) 2020 Adesope et al. This is an open access article distributed under the Creative Commons Attribution License (CCL), which permits unrestricted use, distribution, and reproduction in any medium, provided the original work is properly cited.

Dates: Received: 09 October 2019; Revised: 16 May 2020; Accepted: 12 August 2020

Keywords: Cassava, Cassava flour, Garri, Gross margin, Nigeria

Cassava is a drought resistant crop grown mainly in dry areas; contribute significantly to the nutrition and livelihood of man. It is widely cultivated in Nigeria and is predominantly grown by smallholder farmers. The production of cassava is dependent on a supply of quality stem cuttings. The multiplication rate of these vegetative planting materials is very low compared to that of grain crops which are propagated by seeds. In addition, cassava stem cuttings are bulky and highly perishable as they dry up within few days. As a root crop, cassava roots must be processed into a storable form soon after harvest. Various processing methods such as grating, sun drying and fermenting are used to reduce the cyanide content. Though it is the cheapest source of calories for both human and animal consumption, cassava plays a major role in the country's food security. More than, $80 \%$ of Nigerians reside in the rural areas and they eat cassava meals at least once a day. When compared with rice and maize, cassava has a carbohydrate content which is about $40 \%$ higher than rice and $25 \%$ more than maize (Nyerhovwo, 2004).. It is consumed in different traditional dishes which vary from country to country *Corresponding Author Email: adesope.aa@frin.gov.ng and across communities in a country (Abbas, 2008). Cassava is not only perceived as food but also as a raw material for various types of industries. It can be converted into a large number of products ranging from traditional and novel food products to livestock feeds, ethanol, starch and its numerous derivatives. Cassava is processed into garri within a production cycle that takes an average of five to seven days this is also applies to cassava flour. According to the Integrated Cassava Project (ICP) (2007), the basic stages in cassava flour production are: sorting, washing, peeling, detoxification, drying, grating, sieving, frying, pressing/fermentation, milling and packaging. The profitability of any cassava factory depends primarily on year- round availability of cassava tubers in sufficient quantity, abundant and reliable water supply, transport facilities and availability of capital and labour (Okuneye, 2002). Numerous studies have been conducted on either the profitability or otherwise of either cassava flour or garri in virtually all the major production zones in Nigeria. However, a common peculiarity has not been addressed. In most of the smallholder farming 
households, women are the main processors of cassava in the household. They are versatile in the processing and marketing of garri and cassava flour, and in most cases, they do it simultaneously to diversify their processing and marketing. This peculiarity is common with processors in Ibarapa North LGA. Within the limit of literature consulted, no study has evaluated the profitability of both the cassava flour and garri production. The study therefore, sought to evaluate the profitability or otherwise of cassava flour and garri production in the study area.

\section{MATERIALS AND METHODS}

The study was carried out in Ibarapa North Local Government Area of Oyo State, Nigeria, with an estimated population of over 101,092 people (NPC, 2006). The major occupation of the inhabitants of this local government is farming. Primary data were collected through the use of a structured questionnaire involving 150 randomly selected cassava processors in 15 villages across the local government. Descriptive statistics were used to analyse the socioeconomic characteristics of the respondents in the study area. Gross margin analysis was used to determine the costs and returns on cassava flour and garri production while linear regression analysis was used to identify the factors affecting cassava flour and garri production.

$$
\mathrm{GM}=\mathrm{TR}-\mathrm{TVC}
$$

Where GM = Gross Margin; TR = Total Revenue; $\mathrm{TVC}=$ Total Variable Cost

$$
\lambda=f(Q t s, T r p, S t c, P l c, \text { Gtc, } \operatorname{Pr} c, F r c, P k c)
$$

Where, Qts = Quantity sold in bags (kg); Trp = Transportation; Stc $=$ Storage cost; Plc $=$ Peeling cost; Gtc $=$ Grating cost; Pr $c=$ Pressing cost; Frc $=$ Frying cost; $P k c=$ Packaging cost

\section{RESULTS AND DISCUSSION}

Socioeconomic characteristics of the respondent's: Table 1 reveals that $70 \%$ of the respondents were female while $30 \%$ were male this shows that garri production was a female dominated agribusiness in the study, majority $(46.6 \%)$ were between the ages of 30 and 39 years, $53.3 \%$ of them were married and $11,7 \%$ are single, most of the respondent's $(71.7 \%)$ had one form of formal education while only $28.3 \%$ had no formal education, been educated is likely to increase the efficiency of the garri producers in the study, 35.0 $\%$ had family size between 4 and $6,31.7 \%$ had between $1-3$ and $23.3 \%$ had family size between 7 and 9 persons this therefore shows that the respondent's had fairly number of family size which may likely be used as family labour in garri production in the study area.

\begin{tabular}{|c|c|c|}
\hline Variables & Frequency & Percentage (\%) \\
\hline \multicolumn{3}{|l|}{ Gender } \\
\hline Male & 18 & 30.0 \\
\hline Female & 42 & 70.0 \\
\hline Total & 60 & 100.0 \\
\hline \multicolumn{3}{|l|}{ Age (Years) } \\
\hline $20-29$ & 16 & 26.7 \\
\hline $30-39$ & 28 & 46.6 \\
\hline $40-49$ & 9 & 15.0 \\
\hline $50-59$ & 4 & 6.7 \\
\hline 60 and above & 3 & 5.0 \\
\hline Total & 60 & 100.0 \\
\hline \multicolumn{3}{|l|}{ Marital status } \\
\hline Single & 7 & 11.7 \\
\hline Married & 32 & 53.3 \\
\hline Divorce & 13 & 21.7 \\
\hline Widow & 8 & 13.3 \\
\hline Total & 60 & 100.0 \\
\hline \multicolumn{3}{|l|}{ Religion } \\
\hline Christianity & 16 & 26.7 \\
\hline Islamic & 30 & 50.0 \\
\hline Traditional & 14 & 23.3 \\
\hline Total & 60 & 100.0 \\
\hline \multicolumn{3}{|l|}{ Educational level } \\
\hline No formal education & 17 & 28.8 \\
\hline Primary education & 14 & 23.3 \\
\hline Secondary education & 18 & 30.0 \\
\hline Tertiary education & 11 & 18.3 \\
\hline Total & 60 & 100.0 \\
\hline \multicolumn{3}{|l|}{ Family size } \\
\hline $1-3$ & 19 & 31.7 \\
\hline $4-6$ & 21 & 35.0 \\
\hline $7-9$ & 14 & 23.3 \\
\hline 10 and above & 6 & 10.0 \\
\hline Total & 60 & 100.0 \\
\hline
\end{tabular}

Table 1: Socioeconomic characteristics of respondents on Garri

Regression Analysis for Garri Production: From the table 2, the regression analysis shows that the quantity of garri sold is positively significant while transportation and peeling cost are negatively significant to the total revenue accruing from the sale of garri. This implies that an additional $\mathrm{kg}$ (kilogram) of garri sold increases the total revenue by $\sharp 6.17$.

Table 2: Determinants of Profitability in Garri Processing and

\begin{tabular}{lll}
\multicolumn{3}{c}{ Marketing } \\
\hline Explanatory Variable & Estimate & T Value \\
\hline Quantity sold in bags (kg) & $6.1729 * * *$ & 9.73 \\
Transportation & $-0.3101 *$ & -1.81 \\
Storage cost & 0.0060 & 0.05 \\
Peeling cost & $-1.7658^{* *}$ & -2.13 \\
Grating cost & 0.9961 & -0.95 \\
Pressing cost & 1.2590 & 0.84 \\
Frying cost & 0.0839 & 0.43 \\
Packaging cost & 0.0326 & 0.05 \\
Source: Authors' computation; *** = Significant at 1\%, ** $=$ \\
Significant at 5\%, * Significant at 10\%; Adjusted R squared $=$ \\
\multicolumn{2}{c}{ 66\% }
\end{tabular}
$66 \%$ 
Also, for every additional $\$ 1$ transportation cost incurred, the total revenue realized from the sale of garri will reduce by 31 kobo. And also for every additional $\$ 1$ peeling cost incurred, the total revenue from the sale of garri will reduce by $\$ 1.76$.

Regression Estimates for Cassava Flour Production: The quantity sold in bags, transportation cost, peeling cost and slicing cost are all significant with regard to the total revenue from the flour sales (Table 3). It can be explained that for every additional $\$ 1$ gained from the quantity sold in bags, the revenue realised from flour will increase by $\$ 5.40$. On the contrary, for every additional $¥ 1$ transportation cost incurred, total revenue realised from flour will reduce by $29 \mathrm{k}$. Also, for every $\$ 1$ additional peeling cost incurred, the revenue realised from flour will reduce by $42 \mathrm{k}$. Finally, for every additional $\$ 1$ slicing cost incurred revenue realised from flour will increase by $68 \mathrm{k}$.

Table 3: Determinants of Profitability in Cassava flour Processing

\begin{tabular}{lll}
\multicolumn{3}{c}{ and Marketing } \\
\hline Explanatory Variable & Estimate & T Value \\
\hline Quantity sold in bags (kg) & $5.4099^{* * *}$ & 12.70 \\
Transportation & $-0.2994^{* * *}$ & -2.96 \\
Storage cost & 0.0131 & 1.24 \\
Peeling cost & $-0.4249^{*}$ & -1.88 \\
Grating cost & $0.6878^{* * *}$ & 2.83 \\
Pressing cost & -0.3963 & -1.45 \\
Frying cost & -0.0716 & -0.27 \\
Packaging cost & 0.1434 & 0.67 \\
Source: Authors' computation; $* * *=$ Significant at $1 \%$, * \\
\multicolumn{2}{c}{ Significant at 10\%.; Adjusted R squared $=71 \%$}
\end{tabular}

Estimated average gross margin of Garri and Cassava flour production: On the basis of the gross margin analysis (Table 4) to determine the profitability of each activity, the average gross margin for garri( 23,627.92) and accounting for $71.8 \%$ of the total gross margin and was higher than the average gross margin of cassava flour $(\$ 9,296.89)$ which accounting for $28.2 \%$ by $\$ 14,331.03$. This shows that garri production is more profitable than flour production, however, the total average gross margin earned by the respondents was $\$ 932,919.81$ indicating that cassava processing was a profitable agribusiness in the study area, this result conform with (Afolabi,2009).

Table 4: Comparison between the Gross margin of Cassava flour and Garri Processing and Marketing

\begin{tabular}{|c|c|c|}
\hline Activities & $\begin{array}{l}\text { Average } \\
\text { Gross Margin }\end{array}$ & $\begin{array}{l}\text { Percentage } \\
(\%)\end{array}$ \\
\hline Garri & 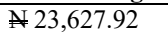 & 71.8 \\
\hline Flour & 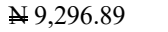 & 28.2 \\
\hline Total & N 932,919.81 & 100.0 \\
\hline
\end{tabular}

Perceived Factors affecting garri production and Marketing: Table 5 shows various factors affecting the production of garri in the study area include e its price, market, pests and diseases, insecurity, farm input, inadequate capital, transportation, water supply, and land tenure among others this is in line with (Ohen et al., 2014 and Oyewo et al., 2014). While 53\% strongly agreed that the price of garri affects its production, $47 \%$ disagreed that policies affect garri production in the study area.

Factors militating against cassava flour production: Table 6 shows that $36 \%$ of the respondents strongly agreed that price is a major factor in the production of cassava flour while $19 \%$ disagreed; $34 \%$ of the respondents strongly disagreed that policy is a major factor in flour production while only $1 \%$ respondents agreed. While $39 \%$ of the respondents disagreed that consumer tasks is a major factor in flour production, $13 \%$ agreed. Although $47 \%$ of the respondents disagreed that market is a major factor affecting flour production, $6 \%$ agreed; $26 \%$ of the respondents strongly disagreed that pest and diseases constitute a major factor in flour production, while $11 \%$ agreed. While $62 \%$ of the respondents agreed that transportation is a major factor in the production of flour, $4 \%$ disagreed. Although $38 \%$ of the respondents disagreed that land tenure is a major factor in the production of flour, $8 \%$ strongly disagreed.

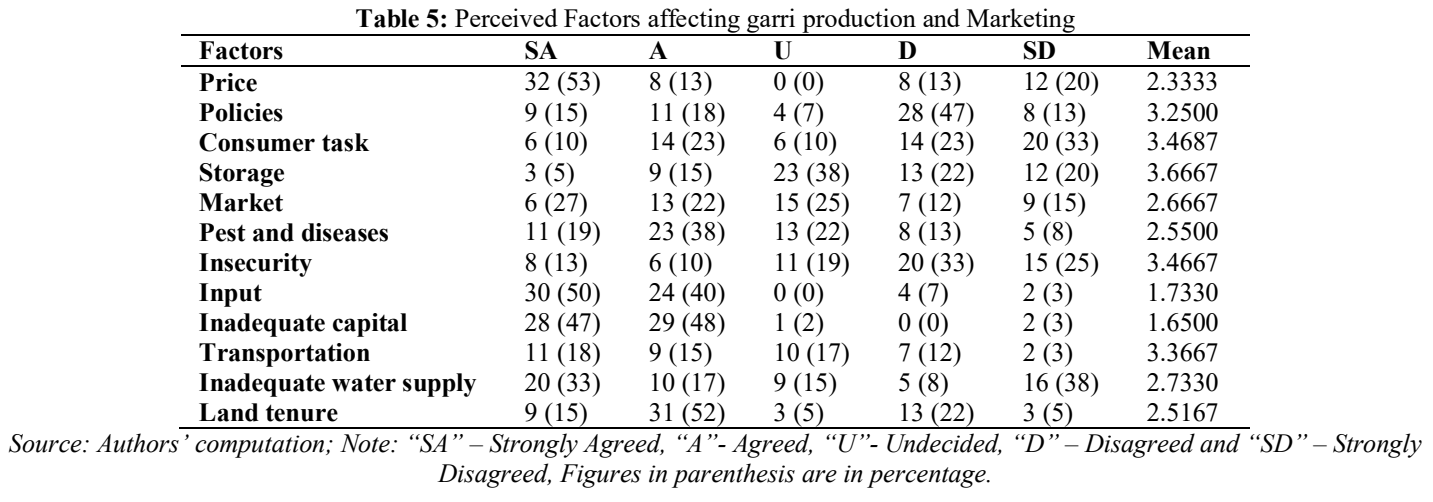




\begin{tabular}{|c|c|c|c|c|c|c|}
\hline Factors & SA & $\mathbf{A}$ & $\mathbf{U}$ & D & SD & Mean \\
\hline Price & $32(36)$ & $28(31)$ & $2(2)$ & $11(1)$ & 17 (19) & 2.4778 \\
\hline Policies & $9(10)$ & $1(1)$ & $30(33)$ & $16(8)$ & $34(38)$ & 3.7222 \\
\hline Consumer task & $17(19)$ & $12(13)$ & 17 (19) & $35(39)$ & $9(10)$ & 3.0722 \\
\hline Storage & $16(18)$ & $14(16)$ & $28(31)$ & $16(18)$ & $16(18)$ & 3.0778 \\
\hline Market & $13(14)$ & $5(6)$ & $21(23)$ & $42(47)$ & $9(10)$ & 3.3222 \\
\hline Pest and diseases & $21(23)$ & $10(11)$ & $16(18)$ & $20(22)$ & $23(26)$ & 3.1556 \\
\hline Insecurity & $32(36)$ & $42(47)$ & $5(6)$ & $8(9)$ & $3(3)$ & 1.9778 \\
\hline Input & $14(16)$ & $12(13)$ & $31(34)$ & $11(12)$ & $22(24)$ & 3.1667 \\
\hline Inadequate capital & $41(46)$ & $37(41)$ & $7(8)$ & $1(1)$ & $4(4)$ & 1.7778 \\
\hline Transportation & $21(23)$ & $56(62)$ & $4(4)$ & $4(4)$ & $5(6)$ & 2.0667 \\
\hline Inadequate water supply & $54(60)$ & $21(23)$ & $6(7)$ & $4(4)$ & $5(6)$ & 1.7222 \\
\hline Land tenure & $7(8)$ & $5(6)$ & $30(33)$ & $34(38)$ & $14(16)$ & 3.4778 \\
\hline
\end{tabular}

Conclusions: Findings showed that the average gross margin for garri was higher than that for cassava flour. Also, the quantity sold in bags, transportation cost, peeling cost and slicing cost were all significant with regard to the total revenue from the sale of flour. Price, inadequate capital, transportation, land tenure and market were major factors influencing garri and cassava flour production in the study area. The government should provide adequate and subsidies farm input, capital and accessible markets for farmers so as to increase their production and ensure food security

\section{REFERENCES}

Abass, A (2008); Recent Development in Cassava Processing Utilization and Marketing in East and Southern Africa and Lesson Learned. Pp 153-160

Afolabi, JA (2009); An Assessment of Garri Marketing in South-Western Nigeria. J. of Soc Sci. 21 (1): 33-38
Nyerhovwo, JI (2004); "Cassava and the Future Biotechnology Issues for Developing Countries. Electr J. of Biotec, Pointificia Universiel al Catolicade Valparaiso Chile, 7(1): 22-32.

Ohen, SB; Ene, DE;Umeze, GE (2014); Resource use efficiency of Cassava farmers in Akwalbom State, Nigeria. J. Bio, Agric. Healthcare. 4(2): 126-131.

Okuneye. AP (2002); Rising Cost of Food Prices and Food Insecurity in Nigeria and its Implication to Poverty Reduction. CBN Economic and Financial Review, 39 N0. 4 pp 16

Oyewo, IO; Raufu, MO; Adesope, AAA; Akanni, OF; Adio, AA (2014): Factors Affecting Maize Production among Farmers in Oluyole Local Government Area of Oyo State. Sci. Agric. 3 (2):70-75.

NPC (2006). Nigeria Population Commission 